\title{
Chemical Characteristics and Amino Acids Profile of Protein Hydrolysates of Nile Tilapia (Oreochromis niloticus) Viscera
}

\author{
Putut Har Riyadi $^{1,2 *}$, Eddy Suprayitno $^{3}$, Aulanni'am Aulanni'am $^{4}$ and Titik Dwi Sulistiyati ${ }^{3}$ \\ ${ }^{1}$ Post Graduate Program, Faculty of Fisheries and Marine Sciences, Brawijaya University, Malang 65145, East Java, Indonesia. \\ ${ }^{2}$ Department of Fisheries Product Technology, Faculty of Fisheries and Marine Sciences, Diponegoro University, Semarang 50275, Central Java, \\ Indonesia. \\ ${ }^{3}$ Department of Fisheries Product Technology, Faculty of Fisheries and Marine Sciences, Brawijaya University, Malang 65145, East Java, Indonesia. \\ ${ }^{4}$ Department of Chemistry, Faculty of Mathematics and Natural Sciences, Brawijaya University, Malang 65145, East Java, Indonesia. \\ *Corresponding author's Email: putut.riyadi@live.undip.ac.id; (DORCiD: 0000-0003-2940-4108
}

\begin{abstract}
Research on protein hydrolysate has been performed by using various types of fish and enzymes, but there is limited research on the nutritive value of visceral waste proteins of tilapia. The present study aimed to determine amino acid profile and composition (water, protein, fat and ash content) of protein hydrolysates prepared from viscera of Nile tilapia (Oreochromis niloticus). Alcalase enzyme was used as the hydrolytic enzyme at a concentration of $1.5 \%$ $(\mathrm{w} / \mathrm{v}), \mathrm{pH} 7.9$, and temperature of $55.80{ }^{\circ} \mathrm{C}$ for $1.5 \mathrm{~h}$. Fresh Nile tilapia viscera had a high protein content of $35.14 \%$ \pm 0.02 (dry basis) and the defatting process reduced fat content from $60.24 \pm 0.04$ to $57.81 \% \pm 0.01$ (dry basis). The results indicated that the hydrolysis of Nile tilapia viscera led to an increase in the protein content $(62.81 \% \pm 0.18)$ (dry basis). Furthermore, hydrolysis process also decreased the moisture content $(11.56 \% \pm 0.49)$, fat content $(16 \%$ $\pm 0.14)$, and ash content $(5 \% \pm 0.17)$ (dry basis). Glutamine had the highest amino acid level in hydrolysates $(3.85$ $\mathrm{g} / 100 \mathrm{~g})$, whereas cysteine the lowest level $(0.32 \mathrm{~g} / 100 \mathrm{~g})$. In conclusion, Nile tilapia protein hydrolysates contain sufficient quantities of the essential amino acids that can be used as a source for fish feed protein. Moreover, chemical characteristics and amino acid profile of Nile tilapia protein hydrolysates indicated a high nutritional value which could be met adult human nutritional needs.
\end{abstract}

Key words: Chemical characteristics, Protein hydrolysates, Tilapia, Viscera.

\section{INTRODUCTION}

The increase of tilapia production results in increased fish waste such as head, skin, fins, tail, bone, viscera, and fish scales. Nowadays, parts of head, bone, fin, and tail are commonly consumed as fish head curry and fish skin crackers, but the viscera are usually not consumed. In recent years, the total of tilapia viscera weight was 115,537 tons (Directorate General of Aquaculture, 2018). Fish viscera has high levels of unsaturated fat and protein (Bhaskar and Mahendrakar, 2008) thus fish waste can be used for the production of various value products on a large scale (Chalamaiah et al., 2012). The protein content in viscera of sturgeon (Acipenser persicus), Catla (Catla catla), and barramundi (Lates calcarifer) is $15.48 \%, 8.52 \%$, and $11.34 \%$ (Bhaskar et al., 2008; Ovissipour et al., 2010; Nurhayati et al., 2014).

Fish viscera can be used as a source of raw material for the production of proteins hydrolysate and leads to a decrease in discarding fish waste and consequently environmental problems (Villamil et al., 2017). Protein hydrolysates are obtained from a chemical or biological process of breaking down the protein to peptides by partial or extensive hydrolysis using enzyme, acid, or alkaline (Kim and Wijesekara, 2010). At optimized conditions in terms of $\mathrm{pH}$, temperature and hydrolysis time, a hydrolysis reaction produces high-quality protein hydrolysates (Halim et al., 2016). Hydrolysis by enzymes specifically produces the peptides and essential amino acids (Zambrowicz et al., 2013). Fish protein hydrolysate production of viscera has been done using a number of proteolytic enzymes including Protamex, Alcalase, Neutrase, Flavorzyme, trypsin, pepsin, $\alpha$-chymotrypsin (Bhaskar and Mahendrakar, 2008; Bougatef et al., 2008; Batista et al., 2010; Ovissipour et al., 2012). Several studies have also reported the use of an endogenous enzyme from viscera to produce fish protein hydrolysate (Bougatef et al., 2008; Klomklao et al., 2013; Khaled et al., 2014). Alcalase is one of most widely enzymes used by many researchers for protein hydrolysates production (Bougatef et al., 2008; Ovissipour et al., 2010; Dufossé et al., 2015; Roslan et al., 2015). Alcalase enzyme might be considered as the best candidate for enzymatic hydrolysis of fish protein (Kristinsson and Rasco, 2000). 
Fish viscera has a high-fat content and negatively affect the success of the hydrolysis process. Thus, it is necessary to remove the fat component in this process. Defatting is an effective factor in optimal hydrolysis and maintaining product stability during storage (Bhaskar and Mahendrakar, 2008). Research on protein hydrolysate has been performed by using various types of fish and enzymes, but there is limited research on the utilization of visceral waste proteins of tilapia and their nutritional value. The purpose of this study was to determine the proximate composition and amino acid profile of protein hydrolysates of Nile tilapia viscera.

\section{MATERIALS AND METHODS}

Tilapia viscera was obtained from the PT Aquafarm Nusantara, Semarang Industrial Area, Indonesia, and transported in a cool container box to the laboratory of Fisheries Product Technology, Diponegoro University, Indonesia. The tilapia viscera was cleaned, defatted and weighed, then viscera proximate analysis was performed.

\section{Defatting and hydrolysis process}

Briefly, 500 grams of fish viscera and $500 \mathrm{ml}$ of distilled water were homogenized and heated at $85^{\circ} \mathrm{C}$ for $20 \mathrm{~min}$. Samples were then centrifuged at $5800 \mathrm{rpm}, 10{ }^{\circ} \mathrm{C}$ for $20 \mathrm{~min}$. Then fat residues were discarded and the remaining pellets as protein-rich solids were extracted three times with distilled water at 1:1(w/v) ratio. The protein extract was used for the optimization experiment. A mixture of $50 \mathrm{ml}$ of protein extract and $1.5 \%(\mathrm{w} / \mathrm{v})$ of Alcalase enzyme (Sigma Aldrich, USA) with activity $\geq 0.75$ Anson Units (AU)/ml were incubated at $55.80{ }^{\circ} \mathrm{C}, \mathrm{pH} 7.9$ for $1.5 \mathrm{~h}$. Then, the solution was heated to $80-85^{\circ} \mathrm{C}$ for $20 \mathrm{~min}$ to inactivate the enzyme action. After that, the sample was stored at $4{ }^{\circ} \mathrm{C}$ for $24 \mathrm{~h}$, and cold centrifuged for $20 \mathrm{~min}$ and dried using a freeze-dryer. The degree of hydrolysis was calculated by the method of trichloroacetic acid soluble nitrogen (SN-TCA) (Bhaskar and Mahendrakar, 2008). A total of $20 \mathrm{mg}$ of protein hydrolysates was added to $20 \mathrm{ml}$ trichloroacetic acid $10 \%$ (w/v) (G-Biosciences, USA). The mixture was allowed to stand for $30 \mathrm{~min}$ and then centrifuged $(7,800 \mathrm{~g}, 15 \mathrm{~min})$. The supernatant was analyzed for nitrogen level by the Kjeldahl method (Bhaskar et al., 2008; Bhaskar and Mahendrakar, 2008).

\section{Proximate analysis}

The water content was determined after drying the sample in an oven at $105{ }^{\circ} \mathrm{C}$ for $5 \mathrm{~h}$. The Kjeldahl method was used to determine the levels of crude protein using a protein analyzer Tecator Kjeltec (FOSS, Hillerod, Denmark) (Bhaskar and Mahendrakar, 2008; Bhaskar et al., 2008). The fat content of samples was determined using the soxhlet method (Bhaskar and Mahendrakar, 2008). The ash content was determined by heating the sample in a furnace at $550{ }^{\circ} \mathrm{C}$ for $8-12 \mathrm{~h}$.

\section{Amino acid analysis}

The amino acid composition was identified using a Waters-Pico Tag amino acid analyzer system (Waters 2690/5, Waters Corp., Milford, MA, USA) as described by White et al. (1986). Briefly, the hydrolysis process was carried out by mixing of $0.2 \mathrm{~g}$ sample with $5 \mathrm{~mL}$ of $6 \mathrm{~N} \mathrm{HCl}$ at $110{ }^{\circ} \mathrm{C}$ for $24 \mathrm{~h}$. The hydrolysates were prepared for chromatography. The separation of phenylthiocarbamide derivatives was carried out by high-performance liquid chromatography at 254 nm.

\section{Chemical score}

The chemical score of the protein hydrolysates was computed to the nutritional value of protein hydrolysates of tilapia viscera which is related to the essential amino acid profile in a standard protein as described by FAO/WHO (WHO, FAO, and UNU, 2007). In brief, the chemical score was calculated using the following equation:

$$
\text { Chemical score }=\frac{\text { Essential amino acids in protein test }\left(g 100 g^{-1}\right)}{\text { Essential amino acids in protein standard }\left(g_{\left.100 g^{-1}\right)}\right.}(1)
$$

\section{Statistical analysis}

Data were analyzed by ANOVA and Duncan's multiple range test, using the Design Expert 11.0® program (Statease Inc., Minneapolis, Minn., A.S.A.).

\section{RESULTS AND DISCUSSION}

The results of the study showed that the protein content of tilapia viscera on a dry basis (35.14\%) was greater than barramundi viscera (31.20\%) (Nurhayati et al., 2014) but lower than Catla (35.87\%) (Bhaskar et al., 2008) (Table 1). A high-fat content of tilapia viscera was $60.24 \%$ (dry basis). Cultivated fish tend to have a high-fat content caused by the type of feed. The fat content could disrupt the hydrolysis process and affect the shelf life (Nurhayati et al., 2014). 
The defatting process of tilapia viscera reduced the fat content around $2.37 \%$ (dry basis) (Table 2). The defatting process of barramundi and Catla viscera reduced the fat content to $2.95 \%$ and $31.15 \%$ (dry basis) of the total fat in raw materials, respectively (Bhaskar et al., 2008; Nurhayati et al., 2014). The insignificant reduction in fat is caused by incomplete homogenization and the single-step centrifugation process. The intestinal component is difficult to mix because it has a simple columnar epithelium covering a sub-mucosa. The columnar epithelium contains eosinophilic cells that are bounded by the mucosal layer and fibro elastic layer (Thiansilakul et al., 2007). The defatting process of Catla viscera had been performed using centrifugation in two phases at the same speed and temperature (Bhaskar et al., 2008). Defatting the tilapia viscera led to a decrease in the protein content by $2.69 \%$. Declined levels of protein are due to the heat given during the defatting process, results in the dissolution of proteins in water (Thiansilakul et al., 2007).

At optimum condition, the degree of hydrolysis by Alcalase was found at $39.11 \%$. The water content of the dried hydrolysates was $11.56 \pm 0.49$, which was greater than barramundi hydrolysates (10.82\%) (Nurhayati et al., 2014), and Catla fish (7.66\%) (Bhaskar et al., 2008) (Table 3). The difference in water content can be attributed to different drying methods. Freeze dryer was used for tilapia viscera and barramundi viscera, while the spray drier was used for Catla viscera. The drying process is performed to minimize the water content for the best shelf life of the hydrolysates (Ovissipor et al., 2010). The level of protein content in the hydrolysates of tilapia viscera was $55.55 \% \pm 0.18$. The increase in the protein level of hydrolysate products is due to the release of soluble nitrogen compounds (Ovissipour et al., 2012).

Table 1. Proximate body composition of the fresh Tilapia viscera, Barramundi viscera and Catla viscera

\begin{tabular}{lcccccc}
\hline \multirow{2}{*}{ Component } & \multicolumn{2}{c}{ Tilapia viscera $(\%)$} & \multicolumn{2}{c}{ Barramundi viscera $(\%)^{*}$} & \multicolumn{2}{c}{ Catla viscera $(\%)^{* * *}$} \\
& Wet Basis & Dry Basis & Wet Basis & Dry Basis & Wet Basis & Dry Basis \\
\hline Moisture & $91.17 \pm 1.22$ & & 63.66 & -- & 76.15 & -- \\
Protein & $3.10 \pm 0.02$ & $35.14 \pm 0.02$ & 11.34 & 31.20 & 8.52 & 35.87 \\
Fat & $5.32 \pm 0.04$ & $60.24 \pm 0.04$ & 22.33 & 61.44 & 12.46 & 52.46 \\
Ash & $0.4 \pm 0.04$ & $4.58 \pm 0.04$ & 0.40 & 5.99 & 0.27 & 1.13 \\
\hline
\end{tabular}

All values are the means of triplicate determinations (mean \pm SD). ${ }^{*}$ Reference: Nurhayati et al. (2014); ${ }^{* *}$ Reference: Bhaskar et al. (2008)

Table 2. Proximate body composition of the defatted Tilapia viscera, Barramundi viscera and Catla viscera

\begin{tabular}{|c|c|c|c|c|c|c|}
\hline \multirow{2}{*}{ Component } & \multicolumn{2}{|c|}{ Tilapia viscera $(\%)$} & \multicolumn{2}{|c|}{ Barramundi viscera $(\%)^{*}$} & \multicolumn{2}{|c|}{ Catla viscera $(\%)^{* *}$} \\
\hline & Wet Basis & Dry Basis & Wet Basis & Dry Basis & Wet Basis & Dry Basis \\
\hline Moisture & $83.05 \pm 1.24$ & & 68.32 & & 87.33 & \\
\hline Protein & $5.50 \pm 0.04$ & $32.44 \pm 0.04$ & 7.36 & 23.23 & 8.44 & 66.62 \\
\hline Fat & $9.80 \pm 0.01$ & $57.81 \pm 0.01$ & 18.6 & 58.71 & 2.7 & 21.31 \\
\hline Ash & $1.00 \pm 0.02$ & $5.89 \pm 0.02$ & 1.04 & 3.34 & 1.47 & 11.60 \\
\hline
\end{tabular}

All values are the means of triplicate determinations (mean \pm SD). ${ }^{*}$ Reference: Nurhayati et al. (2014); ${ }^{* * *}$ Reference: Bhaskar et al. (2008)

Table 3. Proximate composition of the protein hydrolysate of Tilapia viscera, Barramundi viscera and Catla viscera

\begin{tabular}{lcccccc}
\hline \multirow{2}{*}{ Component } & \multicolumn{2}{c}{ Tilapia viscera (\%) } & \multicolumn{2}{c}{ Barramundi viscera (\%) } & \multicolumn{2}{c}{ Catla viscera (\%) ${ }^{* * *}$} \\
& Wet Basis & Dry Basis & Wet Basis & Dry Basis & Wet Basis & Dry Basis \\
\hline Moisture & $11.56 \pm 0.49$ & & 10.82 & & 3.85 & \\
Protein & $55.55 \pm 0.18$ & $62.81 \pm 0.18$ & 62.85 & 70.47 & 89.06 & 92.62 \\
Fat & $14.47 \pm 0.14$ & $16.0 \pm 0.14$ & 0.84 & 0.94 & 1.94 & 2.02 \\
Ash & $4.56 \pm 0.17$ & $5.0 \pm 0.17$ & 7.30 & 8.18 & 0.45 & 0.47 \\
\hline
\end{tabular}

All values are the means of triplicate determinations (mean \pm SD). ${ }^{*}$ Reference: Nurhayati et al. (2014); ${ }^{* *}$ Reference: Bhaskar et al. (2008)

On a wet basis, the fat content of the protein hydrolysate of tilapia viscera was $14.47 \% \pm 0.14$, which was greater than barramundi viscera and Catla viscera. The fat content of the hydrolysates product is influenced by the characteristics of the raw materials used and the process of fat separation after hydrolysis (Thiansilakul et al., 2007). At the time of the hydrolysis reaction progresses, cell membranes will merge and form a bubble which was not dissolved; it causes the release of fat on the membrane structure (Shahidi, 2007).

On a wet basis, the ash content in the hydrolysis products of tilapia viscera was $4.56 \% \pm 0.17$, which was lower than that in Barramundi viscera (Table 3). The addition of a compound that can form a salt during the hydrolysis process increase levels of ash (Thiansilakul et al., 2007). In the present study, the addition of $\mathrm{NaOH}$ and $\mathrm{HCl}$ compounds to adjust the optimum $\mathrm{pH}$ conditions led to the formation of mineral salts. The most abundant amino acid was glutamine $(3.85 \mathrm{~g} / 100 \mathrm{~g})$, while the lowest amino acid content was in cysteine $(0.32 \mathrm{~g} / 100 \mathrm{~g})$ (Table 4). Glutamine is an amino acid that is most widely found in fishery products (Widyastuti et al., 2014). The results obtained in the current study are 
consistent with other studies that reported glutamine is the highest content in Catla viscera hydrolysates $(15.01 \mathrm{~g} / 100 \mathrm{~g})$ (Bhaskar et al., 2008) and sturgeon viscera hydrolysates (13.70 g/100g) (Ovissipour et al., 2010).

Protein quality can be determined based on the content of essential amino acids. The essential amino acids found in the tilapia protein hydrolysates were higher than other sources of protein. The essential amino acids contained in the hydrolysates protein of tilapia viscera were $55.48 \%$ of the total amino acids. Hydrolysate can be used as a source of fish feed protein with at least $30 \%$ of essential amino acids (Bhaskar et al., 2008). The chemical score provides an estimate of the nutritional value of some protein (Ovissipour et al., 2010). The amino acid profiles of the tilapia viscera hydrolysates were generally higher in essential amino acids compared to the suggested amino acid pattern recommended by FAO/ WHO for adult humans except for methionine.

Table 4. Comparison between the amino acid composition of tilapia visceral protein hydrolysates and FAO/WHO reference protein

\begin{tabular}{|c|c|c|c|}
\hline \multirow[b]{2}{*}{ Amino Acid } & \multicolumn{2}{|c|}{ Quantity (g/ 100 g) } & \multirow{2}{*}{$\begin{array}{c}\text { Chemical score } \\
\text { Reference Protein }^{b}\end{array}$} \\
\hline & $\begin{array}{c}\text { Fish visceral protein } \\
\text { hydrolysate }\end{array}$ & Reference protein $^{\text {a }}$ & \\
\hline \multicolumn{4}{|l|}{ Essential amino acids $(59.84 \%)$} \\
\hline Histidine & 2.04 & 1.6 & 1.28 \\
\hline Isoleucine & 1.56 & 1.3 & 1.20 \\
\hline Leucine & 2.19 & 1.9 & 1.15 \\
\hline Lysine & 2.82 & 1.6 & 1.76 \\
\hline Methionine & 0.88 & 1.7 & 0.52 \\
\hline Phenylalanine & 1.07 & - & - \\
\hline Tyrosine & 1.42 & - & - \\
\hline Threonine & 1.26 & 0.9 & 1.4 \\
\hline Tryptophan & 0.42 & - & - \\
\hline Arginine & 1.93 & - & - \\
\hline Valine & 2.78 & 1.3 & 2.14 \\
\hline \multicolumn{4}{|c|}{ Non-essential amino acids $(40.16 \%)$} \\
\hline Asparagine + aspartate & 3.15 & - & - \\
\hline Glutamine + glutamate & 3.85 & - & - \\
\hline Serine & 1.19 & - & - \\
\hline Glycine & 1.27 & - & - \\
\hline Alanine & 1.56 & - & - \\
\hline Proline/ hydroxy proline & 0.99 & - & - \\
\hline Cysteine & 0.32 & - & - \\
\hline
\end{tabular}

${ }^{\text {a }}$ Suggested profile of essential amino acid requirements for adults (WHO/ FAO/ UNU, 2007); ${ }^{\text {b }}$ Chemical score is calculated with the FAO / WHO reference protein as the base (WHO/ FAO/ UNU, 2007).

\section{CONCLUSION}

The chemical characteristics and amino acid profile of Nile tilapia protein hydrolysates indicated a high nutritional value. Nile tilapia protein hydrolysates contain sufficient quantities of the essential amino acids, therefore, they can be used as a good source of protein for fish feed.

\section{DECLARATIONS}

\section{Acknowledgments}

We would like to acknowledge the Indonesian Endowment Fund for Education (LPDP-BUDI DN), the Ministry of Finance, and the Ministry of Higher Education Research Technology, the Republic of Indonesia for offering a scholarship to the first author for his Ph.D. degree.

\section{Authors' contribution}

Putut Har Riyadi designed the research and wrote the manuscript. Eddy Suprayitno performed the research, Aulanni'am Aulanni'am collected the data and Titik Dwi Sulistiyati contributed to the manuscript review. All authors read and approved the final manuscript.

\section{Competing interests}

The authors have not declared any conflict of interest. 


\section{REFERENCES}

Batista I, Ramos C, Coutinho J, Bandarra NM and Nunes ML (2010). Characterization of protein hydrolysates and lipids obtained from black scabbardfish (Aphanopus carbo) by-products and antioxidative activity of the hydrolysates produced. Process Biochemistry, 45(1): 18-24. DOI: https://doi.org/10.1016/j.procbio.2009.07.019

Bhaskar N and Mahendrakar NS (2008). Protein hydrolysate from visceral waste proteins of Catla (Catla catla): Optimization of hydrolysis conditions for a commercial neutral protease. Bioresource Technology, 99(10): 4105-4111. DOI: https://doi.org/10.1016/j.biortech.2007.09.006

Bhaskar N, Benila T, Radha C and Lalitha R (2008). Optimization of enzymatic hydrolysis of visceral waste proteins of Catla (Catla catla) for preparing protein hydrolysate using a commercial protease. Bioresource Technology, 99: 335-343. DOI: https://doi.org/10.1016/j.biortech.2006.12.015

Bougatef A, Nedjar-Arroume N, Ravallec-Ple R, Leroy Y, Guillochon D, Barkia A and Nasri M (2008). Angiotensin I-converting enzyme (ACE) inhibitory activities of sardinelle (Sardinella aurita) by-products protein hydrolysates obtained by treatment with microbial and visceral fish serine proteases. Food Chemistry, 111(2): 350-356. DOI: https://doi.org/10.1016/j.foodchem.2008.03.074

Chalamaiah M, Kumar BD, Hemalatha R and Jyothirmayi T (2012). Fish protein hydrolysates: Proximate composition, amino acid composition, antioxidant activities and applications: A review. Food Chemistry, 135(4): 3020-3038. DOI: https:// doi.org/10.1016/j.foodchem.2012.06.100.

Directorate General of Aquaculture (2018). Prospek Ikan Nila, Omset Puluhan Juta. Available at: https://kkp.go.id/puslatluh/artikel/2630-prospek-ikan-nila-omset-puluhan-juta

Dufossé L, Galaup P, Yaron A, Arad SM, Blanc P, Murthy KNC and Ravishankar GA (2005). Microorganisms and microalgae as sources of pigments for food use: A scientific oddity or an industrial reality. Trends in Food Science and Technology, 16(9): 389-406. DOI: https://doi.org/10.1016/j.tifs.2005.02.006

Halim NRA, Yusof HM and Sarbon NM (2016). Functional and bioactive properties of fish protein hydrolysates and peptides: A comprehensive review. Trends in Food Science and Technology, 51: 24-33. DOI: https://doi.org/10.1016/j.tifs.2016.02.007

Khaled HB, Ktari N, Ghorbel-Bellaaj O, Jridi M, Lassoued I and Nasri M (2014). Composition, functional properties and in vitro antioxidant activity of protein hydrolysates prepared from sardinelle (Sardinella aurita) muscle. Journal of Food Science and Technology, 51(4): 622-633. DOI: https:// doi.org/10.1007/s13197-011-0544-4

Kim SK and Wijesekara I (2010). Development and biological activities of marine-derived bioactive peptides: A review. Journal of Functional Foods, 2(1): 1-9. DOI: https://doi.org/10.1016/j.jff.2010.01.003

Klomklao S, Benjakul S and Kishimura H (2013). Functional properties and antioxidative activity of protein hydrolysates from toothed ponyfish muscle treated with viscera extract from hybrid catfish. International Journal of Food Science and Technology, 48(7): 1483-1489. DOI: https://doi.org/10.1111/ijfs.12116

Kristinsson HG and Rasco BA (2000). Fish protein hydrolysates: Production, biochemical, and functional properties. Critical Review in Food Science and Nutrition, 40(1): 43-81. DOI: https:// doi.org/10.1080/10408690091189266

Nurhayati T, Salamah E and Nugraha R (2014). Optimization Process Production Hydrolysates of Protein Barramudi Viscera. Jurnal Pengolah Hasil Perikanan, 17(1): 42-52. Available at: https://journal.ipb.ac.id/index.php/jphpi/article/download/8136/6385

Ovissipour M, Kenari AA, Motamedzadegan A, and Nazari RM (2010). Optimization of Enzymatic Hydrolysis of Visceral Waste Proteins of Yellowfin Tuna (Thunnus albacares). Food Bioprocess Technology, 5(2): 696-705. DOI: https:/l doi.org/10.1007/s11947-010-0357-X

Ovissipour M, Safari R, Motamedzadegan A and Shabanpour B (2012). Chemical and Biochemical Hydrolysis of Persian Sturgeon (Acipenser persicus) Visceral Protein. Food and Bioprocess Technology, 5(2): 460-465. DOI: https:// doi.org/10.1007/s11947009-0284-x

Roslan J, Kamal M, Yunos KF and Abdullah N (2015). Optimization of enzymatic hydrolysis of tilapia (Oreochromis niloticus) byproduct using response surface methodology. International Food Research Journal, 22(3): 1117-1123. Available at: http://www.ifrj.upm.edu.my/22\%20(03)\%202015/(34).pdf

Shahidi F (2007). Maximizing the value of marine by-products. Woodhead Publishing Limited, USA.

Thiansilakul Y, Benjakul S and Shahidi F (2007). Compositions, functional properties and antioxidative activity of protein hydrolysates prepared from round scad (Decapterus maruadsi). Food Chemistry, 103(4): 1385-1394. DOI: https://doi.org/10.1016/j.foodchem.2006.10.055

Villamil O, Váquiro H and Solanilla JF (2017). Fish viscera protein hydrolysates: Production, potential applications and functional and bioactive properties. Food Chemistry, 224: 160-171. DOI: https://doi.org/10.1016/j.foodchem.2016.12.057

WHO/ FAO/ UNU (2007). Protein and Amino Acid Requirements in Human Nutrition. Food and Agriculture Organization of the United Nations, World Health Organization and United Nations University. Geneva, Switzerland.

Widyastuti P, Riyadi PH and Ibrahim R (2014). Quality of fish sauce that made from viscera of marine catfish (arius thalassinus) with different salt concentrations. SAINTEK Perikanan. Indonesian Journal of Fisheries Science and Technology, 9(2): 18-23. DOI: https://doi.org/10.14710/ijfst.9.2.18-23

White JA, Hart RJ and Fry JC (1986). An evaluation of the Waters Pico-Tag system for the amino-acid analysis of food materials. Journal of Clinical Laboratory Automation, 8(4): 170-177. Available at: https://www.ncbi.nlm.nih.gov/pmc/articles/PMC2547673/pdf/JAMMC-08-170.pdf

Zambrowicz A, Timmer M, Polanowski A, Lubec G and Trziszka T (2013). Manufacturing of peptides exhibiting biological activity. Amino Acids, 44(2): 315-320. DOI: https:// doi.org/10.1007/s00726-012-1379-7 